\title{
RECONSTRUCTION OF OIL SPILL TRAJECTORY IN THE JAVA SEA, INDONESIA USING SAR IMAGERY
}

\author{
Amarif Abimanyu' ${ }^{1}$, Widodo S. Pranowo ${ }^{2,3}$, Ibnu Faizal ${ }^{4}$, Najma K.A. Afandi ${ }^{1}$, Noir P. Purba ${ }^{4 *}$ \\ ${ }^{1}$ KOMITMEN Research Group, Universitas Padjadjaran, West Java, 45363, Indonesia \\ ${ }^{2}$ Marine and Coastal Data Laboratory, Marine Research Center, Indonesian Ministry of MarineAffairs \& Fisheries, Pasir \\ Putih II, East Ancol, Jakarta UBR 14430, Indonesia \\ 3.Department of Hydrography, Indonesian Naval Postgraduate School (STTAL), Jakarta \\ ${ }^{4}$ Department of Marine, Universitas Padjadjaran, West Java, 45363, Indonesia \\ *Corresponding author: noir.purba@unpad.ac.id \\ Received: January 27th 2019 / Accepted: February 16 ${ }^{\text {th }}, 2021$ / Published: April $1^{\text {st }}, 2021$ \\ https://DOI-10.24057/2071-9388-2020-21
}

\begin{abstract}
Oil spill phenomena in the ocean possess a very serious threat to ocean health. On the ocean surface, oil slicks immediately start to spread and mostly end up in the ecosystem. Furthermore, it could threaten the organisms living in the ocean or impact nearby coastal area. The aim of this research was to investigate the trajectories of oil spill based on a real accident in the Java Sea. Tracking oil spills using satellite images is an efficient method that provides valuable information about trajectories, locations and the spread intensity. The objective of this study was to periodically track the trajectory of the oil spill from the Karawang incident using Sentinel-1 Synthetic Aperture Radar (SAR) images. Pre-processing of the images consisted of radiometric and geometric corrections. After the corrections, SAR images were mapped and plotted accordingly. To understand the oil spill trajectories in relation to the oceanic processes, the ocean current pattern map and surface wind roses were also analysed. The processed images from July to October 2019 show a trajectory dominated by the oil spill layers movement towards the west to northwest from the original location along with a decrease in the detected oil spill area over time. The identified trajectories of the oil spill followed the ocean current pattern and surface winds. Thus, these two parameters were considered to be the main factors responsible for the oil spill drift.
\end{abstract}

KEY WORDS: The Java Sea, oil spill, satellite SAR imagery, oil spill trajectory, ocean currents, wind

CITATION: Amarif Abimanyu, Widodo S. Pranowo, Ibnu Faizal, Najma K.A. Afandi, Noir P. Purba (2021). Reconstruction Of Oil Spill Trajectory In The Java Sea, Indonesia Using Sar Imagery. Geography, Environment, Sustainability, Vol.14, No 1, p. 177-184 https://DOI-10.24057/2071-9388-2020-21

ACKNOWLEDGEMENTS: We would like to thank all the members of KOMITMEN Research Group (KRG), especially Marine Kenzi and Jaya Kelvin, the Copernicus Program and the European Space Agency for providing the data from the Sentinel-1 satellite and the.

Conflict of interests: The authors reported no potential conflict of interest.

\section{INTRODUCTION}

Oil spills in the ocean are hazardous to the marineecosystem (Kingston 2002; Paine et al. 1996), they negatively affect the economy (Loureiro et al. 2006; Osmanoğlu et al. 2012), human health and society (Aguilera et al. 2010; Major \& Wang 2012) as well as tourism activities (Sulistiyono 2013). Oil discharged in the ocean will immediately start to spread. Moreover, over time, it will get dispersed or degenerated by ocean processes that are collectively called weathering (Akkartal \& Sunar 2008). Oil spills will form a layer on the ocean surface due to a difference in density and prevent oxygen transfer from the atmosphere to the water column. Furthermore, if oil accidentally enters marine organisms, it will interfere with the organs and they can be seriously harmed (Almeda et al. 2013; Incardona et al. 2011). Oil pollution in the ocean is challenging to clean and needs a long period to handle and manage, especially if they reach nearby coastal cities (S.E. Chang et al. 2014). With all the damage and impact, real-time information becomes increasingly important for decision-makers. Stakeholders are responsible for cleaning and rescuing the ecosystem as well as human habitat by applying mitigation measures (Fingas \& Brown 1997). A study showed that coastal habitats need 20 years to recover from oil spills (Burns et al. 1993).

Previous major oil spills in the world have shown negative impact on the coastal ecosystem and communities. The Deepwater Horizon oil spill in 2010 is one of the more widely known significant oil spills. Studies on the environmental impact of the Deepwater Horizon showed that even several years after the incident, a small number of oil particles remained in the sediments (Barron 2012; Mansir \& Jones 2012). A study on the Exxon Valdez oil spill also showed that five years after the incident the oil remained in the sediments, and it was estimated that it takes up to 30 years for oil to return to background levels (S.E. Chang et al. 2014). One of the more recent oil spills in Indonesia is the Karawang oil spill in 2019 in the Java Sea. Information gathered from the rig's company official website', showed that the oil spill affected several 
coastal communities in the Karawang and Bekasi Regency. It was also stated that clean-up and other measures to respond to the incident were done. It is crucial to monitor the progress of clean-up actions taken after an oil spill incident, and one of the advanced methods for it is using remote sensing (Brekke \& Solberg 2005; Chaturvedi et al. 2019; Filipponi 2019).

To prevent a broader impact of oil spreading, nowadays experts use satellite images on small to large scale cases (Bayramov et al. 2018; Brekke \& Solberg 2005; Fiscella et al. 2000; Kolokoussis \& Karathanassi 2018; Solberg et al. 2007). Remote sensing data are becoming more accessible recently and some of it can be applied to detect oil spills (Harahsheh 2016). Data from active remote sensing instruments such as Synthetic Aperture Radar (SAR) has a vital role in oil spill detection due to its ability to sense the earth's surface in all weather conditions (Solberg et al. 2007). For example, the new mission satellite, Sentinel-1, which has one of the active sensors developed by the European Consortium, was launched in 2014 (https://sentinel.esa. int). The primary mission objectives are to monitor marine environment including sea ice, ocean waves and oil spills. The research related to detection and mapping of oil spills using SAR from Sentinel-1 satellite has shown that the satellite is capable of detecting oil spills. Prastyani and Basith (2018) explored the data by using an automatic and semi-automatic process to evaluate the oil spreads in Balikpapan Bay (Prastyani \& Basith 2018). Chaturvedi et al. (2019) mentioned that SAR Sentinel-1 and other SAR data that have high resolution could be used to detect oil spills in different marine locations (Chaturvedi et al. 2019). Furthermore, Suneel et al. (2019) explored satellite data to identify oil leaks in the Arabian Sea and their correlation with the oceanographic conditions in the area (Suneel et al., 2019). In this context, the objective of this research was to use satellite SAR images to detect trajectories of the oil leakage produced by an oil platform in the Java Sea. Oil leaks (oil spills) were first noted on July 12, 2019, and spread over the sea for several months (PHE, 2019). The surrounding area of the Java Sea is a critical zone as it represents a necessary and prominent location for living, providing a roof for millions of people, fishing catch areas and ensuring the sustainability of coastal ecosystem (Purwanto 2003).

\section{MATERIALS AND METHODS}

\section{Geographic Location}

The focus area of the research was located near the platform (YYA-1), embedded in the coastal area of the Java Sea $\left(6.09417^{\circ} \mathrm{S}, 107.6257^{\circ} \mathrm{E}\right)$. The affected coastal areas are the Bekasi and Karawang Region. The rig is controlled and managed by Pertamina Hulu Energi (PHE), a national oil company. The ocean basin surrounding the Java Sea is mainly shallow, with a depth of about 60 meters (Simanjorang et al. 2018) (Figure 1). These surrounding waters are also affected by Monsoon, tides, and the Indonesian Throughflow current (Purba \& Pranowo 2015; Siregar et al. 2017).

The YYA-1 oil rig is located near the coastal area of Java Island, north of Karawang and approximately $10 \mathrm{~km}$ off the mainland. From the historical data, the oil leaks were noticed on July 12, 2019, when they were doing the reentry during the re-perforation activities (PHE 2019). From «Daily Update Sumur YYA-1», it was noted that gas bubbles were the first sign of leakages seen from the YYA-1 rig.

\section{Dataset}

The data used in this study are Sentinel-1 SAR images acquired in the Interferometric Wide (IW) mode as Ground Range Detected (GRD) products with vertical-vertical (V) and verticalhorizontal (VH) polarization'. These images can be used as an effective way to map oil spills. Backscattering of the SAR signal over the ocean is mainly due to the sea surface roughness, i.e., a portion of small gravity-capillary waves having a similar radar wavelength scale. Oil film dampens the short gravity-capillary waves on the sea surface and thus the backscatter, which makes spills visible in SAR images as dark spots. In contrast, the surrounding oil-free sea surface appears fairly bright (Topouzelis \& Singha 2017).

Based on the European Space Agency (ESA) database, the appropriate satellite SAR images of the area of interest that are downloadable were taken in July (18 and 30), August (11 and 23), September (4, 16, and 28), and October (22). The first step of the process was downloading the data for the specified location and date. The next step was pre-processing, that included radiometric and geometric corrections that were
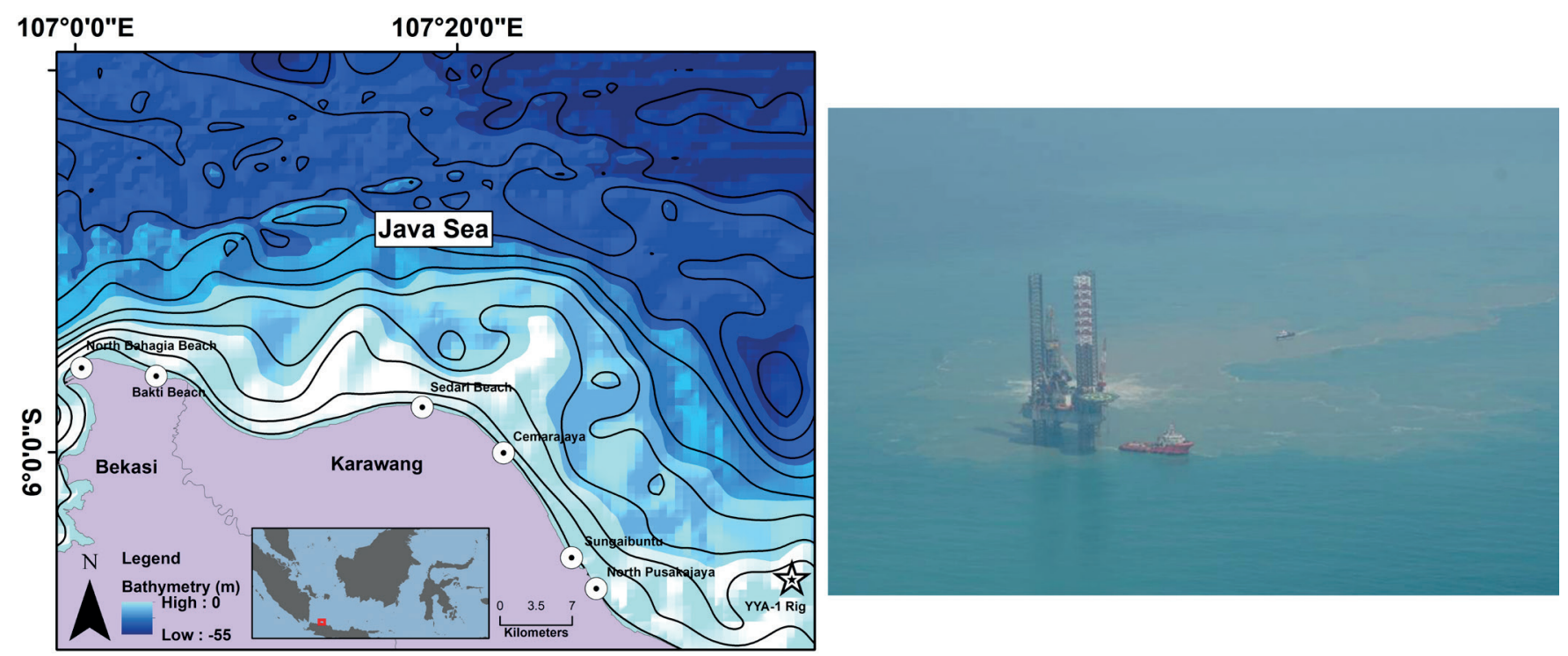

Fig. 1. Left: the geographic area of interest with the YYA-1 oil rig (star), bathymetric map and plots of potentially affected coastal areas; right; situation around the YYA-1 rig after oil leakage (photo by PHE) 


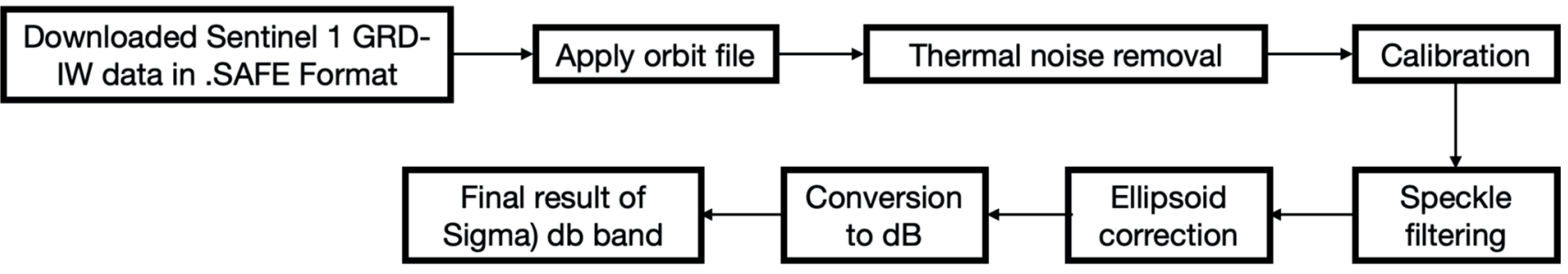

Fig. 2. Workflow for the pre-processing of Sentinel 1 data, adopted from (Chaturvedi et al. 2019; Filipponi 2019)

adopted from (Chaturvedi et al. 2019; Filipponi 2019) (Figure 2). Further information about these processes is accessible through website'. We used the Sentinel Application Platform Radar Toolbox (SNAP) from ESA to process the data. The radiometric correction was done using a Gamma MAP filter with a filter size of $3 \times 3$. The geometric correction was carried with the Ellipsoid Correction-Geolocation Grid to represent the location in the real world. After correction, the $\mathrm{W}$ band from the image was converted to a dB image, which was later analysed. Areas that appear significantly darker than the surrounding waters were interpreted as oil spill areas. The pixel profiles of these areas were analysed as oil spills are marked by the lower pixel values than their clear water surroundings (Prastyani \& Basith 2018).

One of the main challenges in detecting and mapping the oil spill areas was distinguishing between oil slick layer and its look-alikes. Look-alikes are areas that also appear to be darker much like oil slick layer (Ivanov 2011). Look-alikes in the tropical waters can appear due to internal waves, shear zones, low wind and rain cells (Espedal 1999). An example profile plot was made (Figure 3) across the area of clear water and oil spill to demonstrate the difference in pixel values (Prastyani \& Basith 2018).

Generally, the sea surface that has been polluted by oil would have lower pixel values or appear darker in the image. Based on the graph from Figure 3, the pixels with oil spills have lower values by about 2 to $4 \mathrm{~dB}$ than the surrounding clear water.

For ocean current, data from the CMEMS² with daily temporal resolution and 0.08 spatial resolution were used. As for wind data (U10), the data from microwave radiometer downloaded from $\mathrm{APDRC}^{3}$ with a spatial resolution of $0.25^{\circ}$ were used. Then, the oil spill trajectories were analysed based on their distance and drift direction from the oil rig. For trajectory analysis, ocean currents and wind data were included for a more comprehensive description. Model data on currents and tides are useful to see the behaviour of the oil spill in the ocean. The two factors were reported to influence oil slick movement and distribution in the ocean (Galt 1994).

\section{RESULTS AND DISCUSSION}

Eight satellite SAR images representing the area of interest from July to October 2019 were analyzed. Dark pixels in Figure 4 indicate the oil spreading along and near the shoreline. In general, SAR images show movement and distribution of the oil spill towards the west, along the north coast of Karawang Region. This area is home to numerous residents of coastal cities.

From the SAR images of July, it was seen that the oil spill did not spread far away from the oil rig, reaching as far as Cemarajaya Beach (number 4 in the figure). In August, a small area of the oil spill has reached North Bahagia Beach (number 1 in the figure). This point was the farthest detected oil spill area from the rig. The distance from the rig was about $73.7 \mathrm{~km}$, and the direction was around northwest of the rig (Table 1). In September and October, some oil slick layers were also detected north of the rig. It could have happened because of a change in surface current and wind pattern.

Oil slicks movement in the ocean is driven by many oceanic processes, the major ones are winds and currents as they affect the ocean surface (Daling \& StrØm 1999). In the Java Sea, oceanic processes are influenced by many factors, and one of them is the seasonally-shifting monsoonal wind (Sprintall et al. 2014). Winds blow from the dry regions of Australia from June to August (JJA), and from the wetter regions of the Asian continent from December to February (DJF). Other months from the two major seasons are usually referred to as transitional seasons. From the oil spill trajectories shown in Figure 4, it was visible that the monsoonal winds from Australia in the JJA season affected the drift of the oil spill. The oil slick mostly moved westward of the original spill location (YYA-1) in the images from July to August. In September and October, the detected oil spills reduced and were found more northward. This could be due to the clean-up actions and also the transitioning wind pattern. A study in the western part of the Java Sea showed that oil spill trajectories in the Java Sea vary depending on the season (Setyonugroho 2019). The oil spill that occurs in the DJF season will have a more eastward trajectory, and spill that occur in the JJA season will have a more westward trajectory. As shown in Figure 4, the trajectory of the oil spill in this study is more westward in July and August.

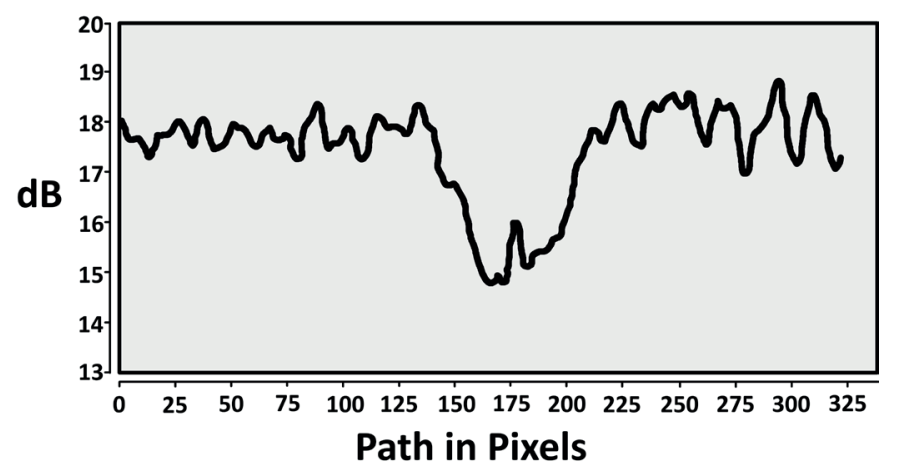

Fig. 3. Profile with an oil slick and clear sea on amplitude SAR image represented in dB

'SAR Images (https://sentinel.esa.ints)

${ }^{2}$ Copernicus Marine Environment Monitoring Service, http://marine.copernicus.eu

${ }^{3}$ Windsat v7.01 from the Asia-Pacific Data Research Center http://apdrc.soest.hawaii.edu 

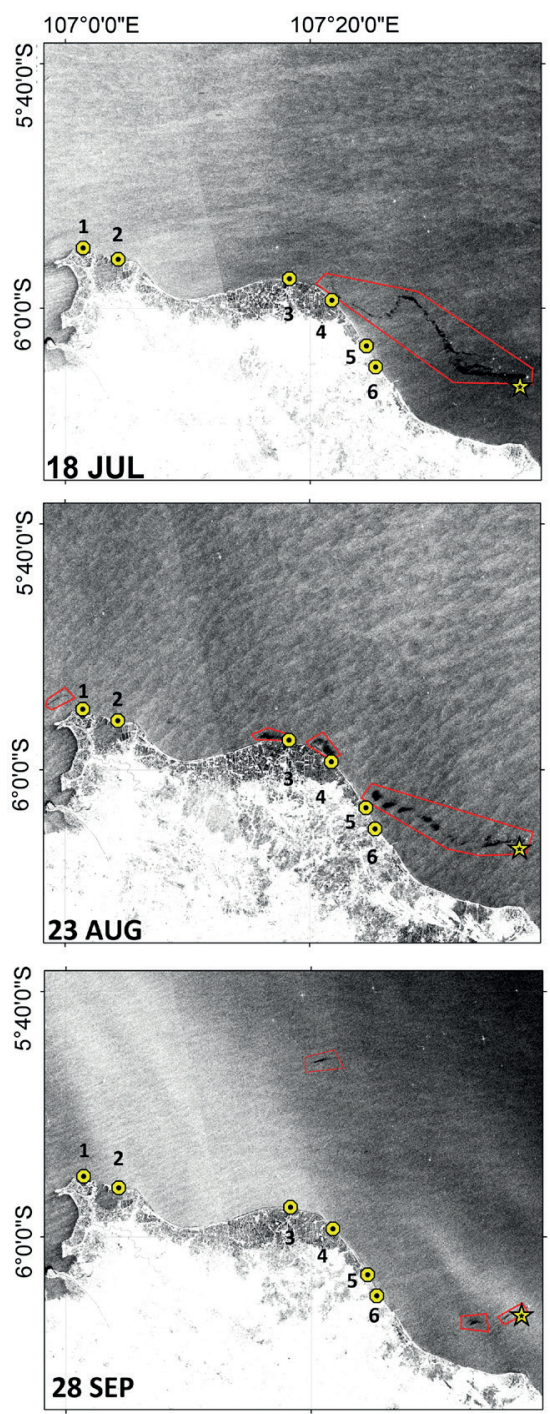
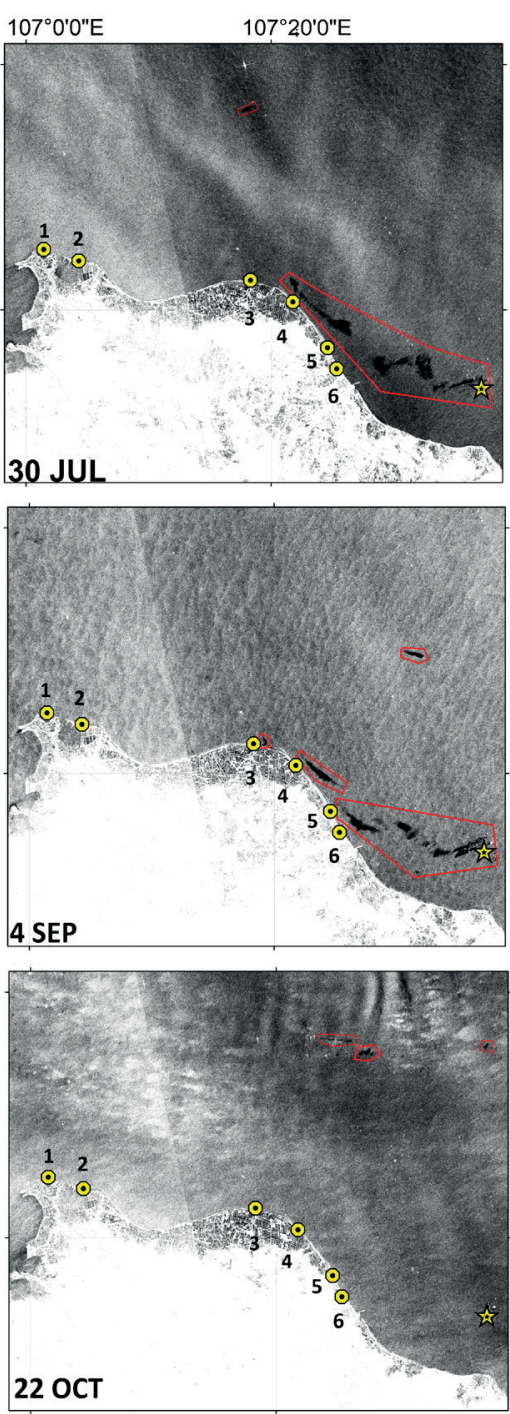
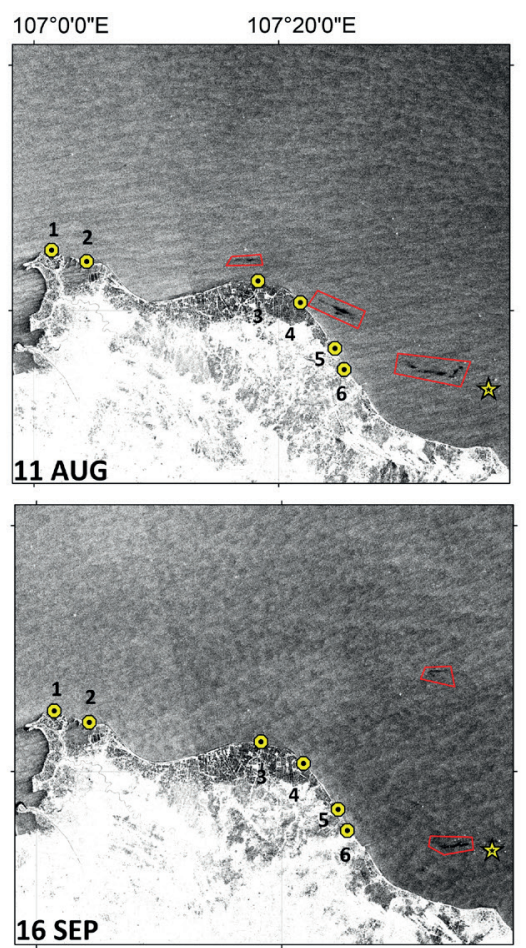

16 SEP 24

Fig. 4. Oil spills and their trajectories on SAR images and near coastal locations: 1) North Bahagia, 2) Bakti, 3) Sedari, 4) Cemarajaya, 5) Sungai Buntu, 6) Pusakajaya and YYA-1 as rig position; dark patches in the red polygons are interpreted as oil spills

Table 1. Distance and drift direction of oil spills from the rig

\begin{tabular}{|c|c|c|c|c|c|c|c|c|}
\hline \multirow{2}{*}{ Date } & \multicolumn{3}{|c|}{ July } & \multicolumn{3}{c|}{ August } & \multicolumn{3}{c|}{ September } & October \\
\cline { 2 - 22 } & 18 & 30 & 11 & 23 & 4 & 16 & 28 & 22 \\
\hline Distance $(\mathrm{km})$ & 32.65 & 33.34 & 43.16 & 73.70 & 37.65 & 7.97 & 26.53 \\
\hline Direction (degree) & 299.58 & 300.11 & 296.20 & 287.57 & 297.28 & 272.88 & 261.63 & 329.58 \\
\hline
\end{tabular}

Table 2. Historical assessment based on PHE reports and satellite image analysis

\begin{tabular}{|c|c|c|}
\hline \multirow{2}{*}{ Date } & \multicolumn{2}{|c|}{ Historical Assessment } \\
\hline & PHE & Satellite Image \\
\hline July, $15^{\text {th }}$ & State of emergency declared & Not acquired \\
\hline July, $16^{\text {th }}$ & Oil sheen visible at the sea surface & Not acquired \\
\hline July, $18^{\text {th }}$ & Oil sheen starts to spread towards the west of YYA-1 Rig & Oil sheen spread towards the west of YYA-1 Rig \\
\hline July, $30^{\text {th }}$ & 8 villages in Karawang and Bekasi are affected & $\begin{array}{l}\text { Oil sheen starts to approach the coastal area of Karawang } \\
\text { (Cemarajaya, Sungai Buntu, Pusakajaya) }\end{array}$ \\
\hline August, $11^{\text {th }}$ & $\begin{array}{c}\text { The oil boom and emergency posts installation along } \\
\text { the coastline of six villages, cleaning of the oil spill in the } \\
\text { affected villages }\end{array}$ & $\begin{array}{l}\text { Area of oil sheen reduced and a small area of oil sheen } \\
\text { detected above Sedari and Cemarajaya }\end{array}$ \\
\hline August, $23^{\text {rd }}$ & $\begin{array}{c}\text { 6,825 meters of shoreline oil boom along Karawang } \\
\text { towards Seribu Islands }\end{array}$ & $\begin{array}{c}\text { Oil sheen detected along the coastal area of Sedari, } \\
\text { Cemarajaya, Sungai Buntu, Pusakajaya, and a small area } \\
\text { around North Bahagia }\end{array}$ \\
\hline
\end{tabular}




\begin{tabular}{|c|c|c|}
\hline September, $4^{\text {th }}$ & $\begin{array}{c}\text { 7,995 meters of shoreline oil boom along Karawang, } \\
\text { Bekasi, and Seribu Islands, } 9 \text { health services posts in } \\
\text { Karawang Regency (Cemarajaya, Tanjung Pakis, Sedari, } \\
\text { Pasir Putih, Tambak Sari, Sungai Buntu, PJU Beach, Cicau } \\
\text { Sri Jaya, Ciwaru) }\end{array}$ & $\begin{array}{c}\text { Oil sheen detected along the coastal area of Sedari, } \\
\text { Cemarajaya, Sungai Buntu, Pusakajaya, and offshore in the } \\
\text { Java Sea }\end{array}$ \\
\hline Septe & $\begin{array}{c}\text { 9,950 metres of shoreline oil boom along Karawang, } \\
\text { Bekasi, and Seribu Islands, cleaning of the oil spill in the } \\
\text { affected villages }\end{array}$ & $\begin{array}{c}\text { No oil sheen detected in the coastal areas of Karawang, oil } \\
\text { sheen detected near the rig, and also a small area in the open } \\
\text { sea }\end{array}$ \\
\hline September, $28^{\text {th }}$ & $\begin{array}{c}\text { 10,185 meters of shoreline oil boom along Karawang, } \\
\text { Bekasi, and Seribu Islands, cleaning of the oil spill in the } \\
\text { affected villages }\end{array}$ & $\begin{array}{c}\text { No oil sheen detected in the coastal areas of Karawang, oil } \\
\text { sheen detected near the rig, and also a small area in the open } \\
\text { sea }\end{array}$ \\
\hline October, $22^{\text {nd }}$ & $\begin{array}{c}\text { 8,625 meters of shoreline oil boom along Karawang, } \\
\text { Bekasi, and Seribu Islands, cleaning of remaining oil spill } \\
\text { in the affected villages }\end{array}$ & $\begin{array}{c}\text { No oil sheen detected around the coastal areas of Karawang } \\
\text { and the rig, small areas of remaining oil sheen detected in the } \\
\text { open sea }\end{array}$ \\
\hline
\end{tabular}

The drift direction of the oil leakage seemed to correspond to the specific direction of ocean currents in the region (Figure 5). According to Figure 4, which shows the evolution of the oil spill from July to September, the oil spills tended to move towards the west, reaching Bekasi and the Seribu Islands. The Java Sea is well known for wind and ocean currents that exist throughout the year. The distribution pattern of the oil spill could be explained by the seasonal wind and current pattern, which around our study period was marked by the north-western current from the lower latitude southeast regions corresponding with the south-eastern monsoon wind, blowing from Australia to the Asian continent (Daruwedho et al. 2016). There was also a decrease in the amount of visible oil slick concentration on the sea surface. This could be due to the actions and cleaning done by the responsible company, oil spills reaching the coast or degradation of oil spill concentration through weathering processes.

As can be seen from the ocean current pattern presented above, there is a steady current flowing towards the west. This could explain a westward distribution pattern which is identified in the processed satellite images. This distribution pattern could be a severe threat to the nearby tourist attraction areas in Karawang, Bekasi, and the Seribu Islands which is a National Park that serves as a home to several crucial ecosystems and protected animals such as sea turtles (Hermawan et al. 1993). The ocean currents at the moment of the spill is probably the most critical factor impacting the distribution of oil. Carls et al. (2001) stated that the tides and currents at the moment of the spill would affect the course of the oil dispersion, while the increased exposure to waves will enhance the mechanical mixing strength (Carls et al. 2001).

In addition to the ocean currents, the direction may be affected by the surface wind pattern. To identify the effect of wind, we analysed wind magnitude and direction around the study area (Figure 6). In June to July, the wind pattern was dominated by winds blowing to the direction of $270^{\circ}-285^{\circ}$ (north-west) with a speed about 5.7 to 8.8 $\mathrm{m} / \mathrm{s}$ and an occurrence percentage of about $21 \%$. From July to August, the wind pattern was similar, dominated by winds blowing to the direction of $270^{\circ}-285^{\circ}$ (north-west) with a speed of about 5.7 to $8.8 \mathrm{~m} / \mathrm{s}$ and an occurrence percentage of around 25\%. From August to September the wind pattern changes slightly and becomes dominated by winds blowing to the direction of $240^{\circ}-255^{\circ}$ (southwest) with a speed about 5.7 to $8.8 \mathrm{~m} / \mathrm{s}$ and an occurrence percentage of around $26 \%$. This wind pattern occurs due to the effect of the Australian Monsoon, which causes dry and warm air from Australia to blow to the Asian continent (some also call it East Monsoon season).

On a planetary scale, the Asian Monsoon is powered by differential heating induced by the regular sunrise and geographical asymmetries of the Eurasian plateau, the Pacific and Indian Oceans, and Antarctica (C.P. Chang et al. 2005; Hung et al. 2004; Li \& Yanai 1996). This Monsoon typically lasts around three months from June to August, but in September the wind patterns are still similar to the three previous months. This could be demonstrated by the greater thermal inertia of the ocean relative to ground. It triggers the natural transition from the boreal summer to winter when the location of the sun is shifted by a month or two. As a result, the forecast winds from September to November are still in the same direction as the boreal summer monsoon on the east of Java (Purba \& Pranowo 2015).

From comparing the windroses with the ocean current patterns, a similarity can be seen between the wind and the ocean current patterns in the surrounding area. The wind blowing over the sea surface generates

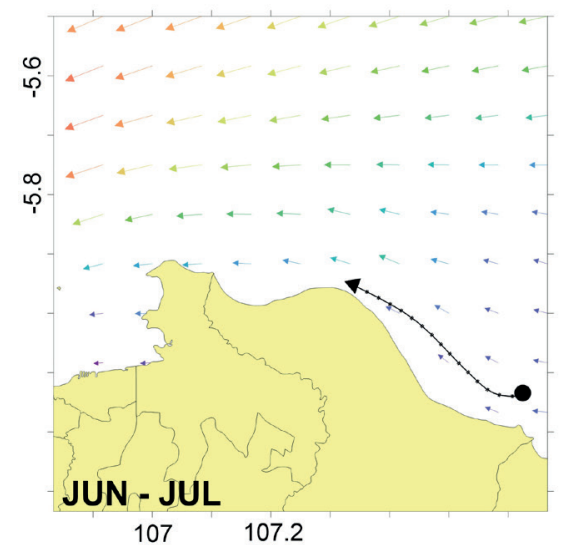

107

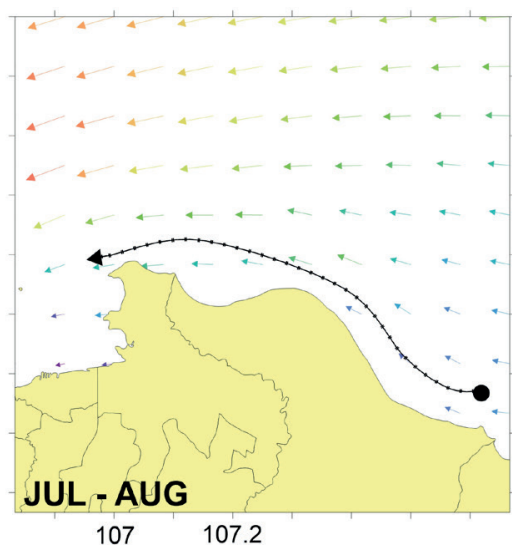

107

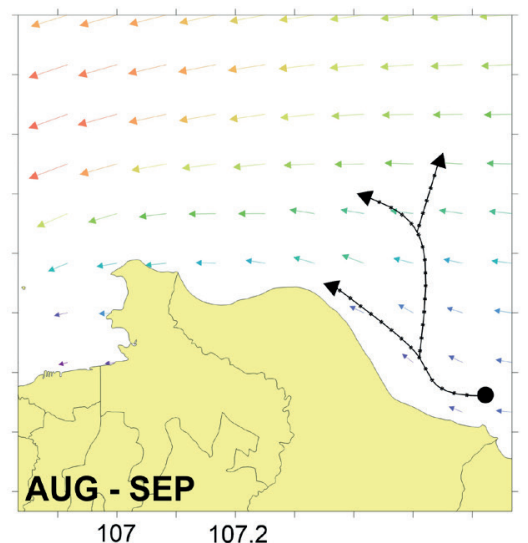

107

107.2

Fig. 5. Ocean current patterns and schematic oil spill trajectories in three months based on the processed SAR images, showing a westward trajectory due to the occurring monsoonal winds from the southeast (Australia) 


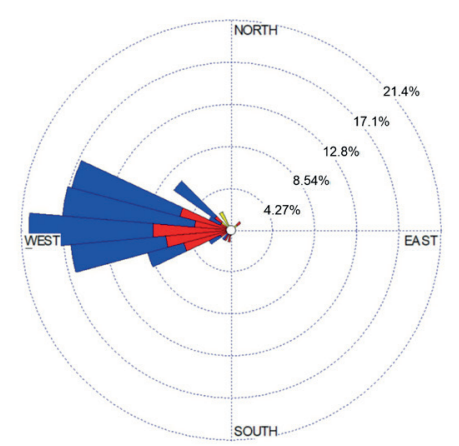

JUN-JUL
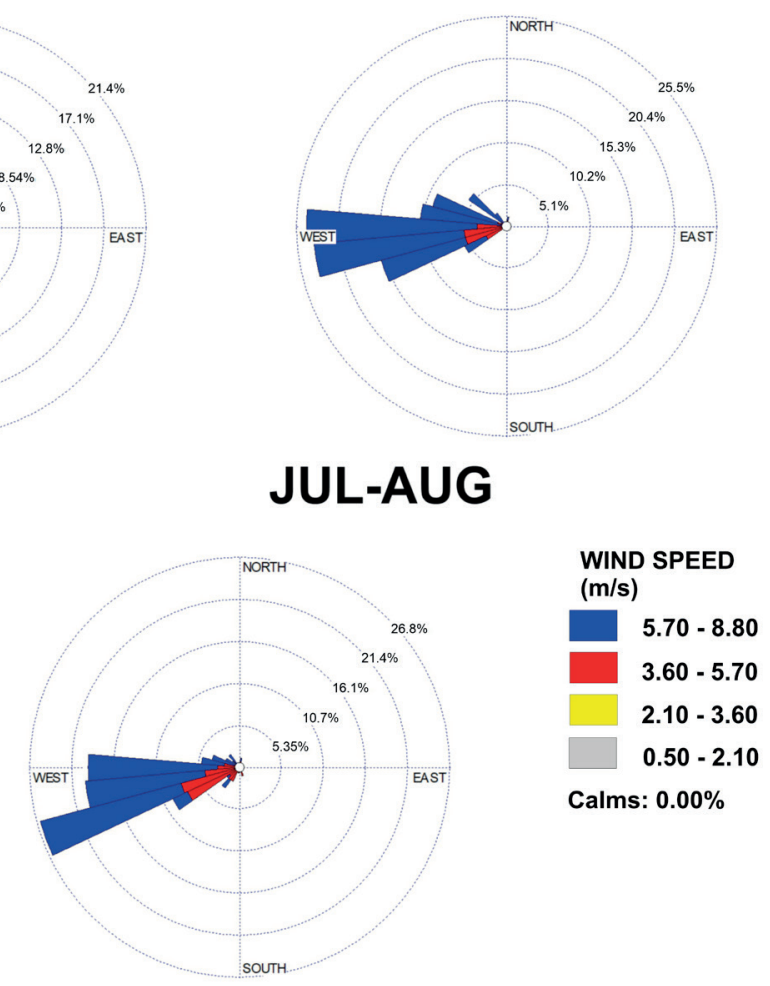

AUG-SEP

Fig. 6. Windroses of surface wind (at $10 \mathrm{~m}$ ) for a station near the YYA-1 rig $\left(6.125^{\circ} \mathrm{S}-107.625^{\circ} \mathrm{E}\right)$ from June to September

wind stress and causes sea motion in the horizontal and vertical direction. In the horizontal direction, it generates cyclonic and anticyclonic patterns which are manifested as sea surface current. At the same time, in the vertical direction, a column of water can develop a complex circulation marked by an upward (upwelling) or downward (downwelling) motion (Sisawnto \& Suratno 2008). Various factors, particularly the wind, influence physical processes on the sea surface. Monsoonal wind plays a vital role as it generates force for a large scale fluid flow in the Indonesian waters. Because of the unique position - between two continents (Australia and Asia) and two oceans (the Pacific Ocean and the Indian Ocean) - the weather and the climate of this region are influenced by annual monsoons. Also, as an archipelago that is passed by the Indonesian Throughflow current (Purba \& Pranowo 2015), Indonesian Region is affected by global phenomenon like the ENSO (EI Niño Southern Oscillation), namely El Niño and La Niña, as well as the Indian Ocean Dipole that regulates the air-sea interaction along with the tropical parts of the Indian and Pacific oceans.

\section{CONCLUSIONS}

This research was done with a purpose to detect and map the trajectory of the oil spill from the Karawang oil spill incident. The results of our work showed that the satellite SAR images provided valuable information about the oil spill drift trajectories even for several months after the accident happened. Oil spill parts were then found far away from the original leakage site. This spread is affected mainly by wind and ocean currents. Oil spills from the rig moved mainly towards the west to northwest from their original location, along the coastal areas. Their trajectories were similar to the ocean current and surface wind patterns. Furthermore, the satellite SAR images from the Sentinel-1 mission can also be noted as one of the empirical satellite data that can be used to track trajectories of oil spills. However, the accuracy of oil spill detection can still be complicated by factors such as low-wind zones and rains that could produce look-alike regions. Further study to better reduce the noise level of the images is also necessary for more accurate oil spill detection.

\section{REFERENCES}

Aguilera F., Méndez J., Pásaro E. and Laffon B. (2010). Review on the effects of exposure to spilled oils on human health. Journal of Applied Toxicology, 30(4), 291-301, DOl: 10.1002/jat.1521.

Akkartal A. and Sunar F. (2008). The usage of radar images in oil spill detection. The International Archives of the Photogrammetry, Remote Sensing and Spatial Information Sciences, XXXVII (B8), 271-276.

Almeda R., Wambaugh Z., Chai C., Wang Z., Liu Z. and Buskey E.J. (2013). Effects of Crude Oil Exposure on bioaccumulation of polycyclic aromatic hydrocarbons and survival of adult and larval stages of gelatinous zooplankton. PLOS One, 8(10), e74476, DOI: 10.1371/journal. pone.0074476.

Barron M.G. (2012). Ecological Impacts of the Deepwater Horizon Oil Spill: Implications for Immunotoxicity. Toxicologic Pathology, 40(2), 315-320, DOI: 10.1177/0192623311428474.

Bayramov E., Kada M. and Buchroithner M. (2018). Monitoring oil spill hotspots, contamination probability modelling and assessment of coastal impacts in the Caspian Sea using SENTINEL-1, LANDSAT-8, RADARSAT, ENVISAT and ERS satellite sensors. Journal of Operational Oceanography, 11 (1), 27-43, DOI: 10.1080/1755876X.2018.1438343.

Brekke C. and Solberg A.H.S. (2005). Oil spill detection by satellite remote sensing. Remote Sensing of Environment, 95(1), 1-13, DOI: 10.1016/j.rse.2004.11.015. 
Burns K.A., Garrity S.D. and Levings S.C. (1993). How many years until mangrove ecosystems recover from catastrophic oil spills? Marine Pollution Bulletin, 26(5), 239-248, DOl: 10.1016/0025-326X(93)90062-O.

Carls M.G., Babcock M.M., Harris P.M., Irvine G.V., Cusick J.A. and Rice SD (2001). Persistence of oiling in mussel beds after the Exxon Valdez oil spill. Marine Environmental Research, 51(2), 167-190, DOI: 10.1016/s0141-1136(00)00103-3.

Chang C.P., Wang Z., McBride J. and Liu C.H. (2005). Annual cycle of Southeast Asia-Maritime Continent rainfall and asymmetric monsoon transition. Journal of Climate, 18, 287-301, DOI: 10.1175/JCLI-3257.1.

Chang S.E., Stone J., Demes K. and Piscitelli M. (2014). Consequences of oil spills: a review and framework for informing planning. Ecology and Society, 19(2), 26, DOI: 10.5751/ES-06406-190226.

Chaturvedi S.K., Banerjee S. and Lele S. (2019). An assessment of oil spill detection using Sentinel 1 SAR-C images, Journal of Ocean Engineering and Science, DOI: 10.1016/j.joes.2019.09.004.

Daily Update Sumur YYA-1. (n.d.). Retrieved from http://phe.pertamina.com

Daling P.S. \& StrØm T. (1999). Weathering of oils at sea: Model/field data comparisons. Spill Science and Technology Bulletin, 5(1), 63-74,

DOI: 10.1016/S1353-2561(98)00051-6.

Daruwedho H., Sasmito B. and Amarohman F.J. (2016). Analisis Pola Arus Laut Permukaan Perairan Indonesia Dengan Menggunakan Satelit Altimetri Jason-2 Tahun 2010-2014. Jurnal Geodesi Undip, 5(2), 145-158 [in Indonesian].

Espedal H. (1999). Detection of oil spill and natural film in the marine environment by space-borne SAR. In Geoscience and Remote Sensing Symposium, 1999. Proceedings of IGARSS'99. IEEE 1999 International, 3, 1478-1480, DOI: 10.1 109/IGARSS.1999.771993.

Filipponi F. (2019). Sentinel-1 GRD pre-processing workflow. The 3rd International Electronic Conference on Remote Sensing, Proceedings MDPI, 18(11), 1-4, DOI: 10.3390/ECRS-3-06201.

Fingas M.F. and Brown C.E. (1997). Review of oil spill remote sensing, Spill Science \& Technology Bulletin, 4(4), 199-208, DOl: $10.3390 \% 2$ Fs 18010091.

Fiscella B., Giancaspro A., Nirchio F., Pavese P. and Trivero P. (2000). Oil spill detection using marine SAR images. International Journal of Remote Sensing, 21(18), 3561-3566, DOI: 10.1080/014311600750037589.

Galt J. (1994). Trajectory analysis for oil spills. Journal of Advanced Marine Technology Conference, 11, 91-126.

Harahsheh H.A. (2016). Oil spill detection and monitoring of Abu Dhabi coastal zone using Kompsat-5 SAR Imagery. The International Archives of the Photogrammetry, Remote Sensing and Spatial Information Sciences, XLI-B8, 2016 XXIII ISPRS Congress, 12-19 July 2016, Prague, Czech Republic, 1-7, DOI: 10.5194/isprs-archives-XLI-B8-1115-2016.

Hermawan D., Silalahi S. and Eidman H.M. (1993). The study of nesting habitat of hawksbill turtle (Eretmochelys imbricata L) in Peteloran Timur and Peteloran Sarat Islands, Marine National Park of Seribu Islands, Jakarta. Jurnal IImu-ilmu Perairan and Perikanan Indonesia, 1(1), 33-37. [in Indonesian]

Hung C.W., Liu X. and Yanai M. (2004). Symmetry and asymmetry of the Asian and Australian summer monsoons. Journal of Climate, 17 , 2413-2426, DOI: 10.1175/1520-0442(2004)017\%3C2413:SAAOTA\%3E2.0.CO;2

Incardona J.P., Collier T.K. and Scholz N.L. (2011). Oil spills and fish health: exposing the heart of matter. Journal of Exposure Science and Environmental Epidemiology, 21, 3-4, DOI: 10.1038/jes.2010.51.

Ivanov A.Y. (2011). Remote Sensing of Oil Films in the Context of Global Changes. Remote Sensing of the Changing Oceans, $169-191$.

DOI: 10.1007/978-3-642-16541-2_9.

Kingston P.F. (2002). Long-term environmental impact of oil spills. Spill Science and Technology Bulletin, 7(1-2), 53-61, DOI: 10.1016/ S1353-2561(02)00051-8.

Kolokoussis P. and Karathanassi V. (2018). Oil spill detection and mapping using Sentinel 2 imagery. Journal of Marine Science and Engineering, 6(4), 1-12, DOl: 10.3390/jmse6010004.

Li C. and Yanai M. (1996). The onset and interannual variability of the Asian summer monsoon in relation to land-sea thermal contrast. Journal of Climate, 9, 358-375.

Loureiro M.L., Ribas A., Lopez E. and Ojea E. (2005). Estimated costs and admissible claims linked to the Prestige oil spill. Ecological Economics, 59, 48-63, DOI: 10.1016/j.ecolecon.2005.10.001.

Major D.N. and Wang H. (2012). How public health impact is addressed: a retrospective view on three different oil spills. Toxicological and Environmental Chemistry, 94, 442-467, DOI: 10.1080/02772248.2012.654633.

Mansir N. \& Jones M. (2012). Environmental impacts of marine oil spill; a case study of Deepwater Horizon oil spill at the Gulf of Mexico United States of America 2010 (a review). Chemsearch Journal, 3(2), 64-70.

Osmanoglu B., Ozkan C., Sunar F. and Staples G. (2012). Automatic calculation of oil slick area from multiple saracquisitions for deepwater horizon oil spill. International Archives of the Photogrammetry, Remote Sensing and Spatial Information Sciences, Vol. XXXIX-B7, 2012 XXII ISPRS Congress, August 25 - September 01 2012, Melbourne, Australia, 63-66, DOI: 10.5194/isprsarchives-XXXIX-B7-63-2012.

Paine R.T., Ruesink J.T., Sun A., Soulanille E.L., Wonham M.J., Harley C.D.G., Brumbaugh D.R. and Secord D.L. (1996). Trouble on oiled waters: lessons from the Exxon Valdez oil spill. Annual Review of Ecology and Systematics, 27, 197-235, DOI: 10.1146/annurev.ecolsys.27.1.197.

PHE (Pertamina Hulu Energi) (2019). Daily Update Sumur YYA-1. http://phe.pertamina.com/ContentView.aspx?MenulD=s2zLDx0/rQH9 umzzIZv74w==\&TypeGroupContent=Y7Ubn6c7hvLjihiwyLyQ/w==\&NewsCatID=jdLumi2w7Hxz4+VktNGHzA==

Prastyani R. and Basith A. (2018). Utilization of Sentinel-1 SAR imagery for oil spill mapping: A case study of Balikpapan Bay oil spill. Journal of Geospatial Information Science and Engineering, 1(1), 22-26, DOI: 10.22146/jgise.38533.

Purba N.P. and Pranowo W.S. (2015). Oceanographic dynamic, water mass and Circulation characteristic, UNPAD Press, Bandung, $50-75$. Purwanto (2003). Status and management of the Java sea fisheries. WorldFish Center and Asian Development Bank.

Setyonugroho A., Damar A. and Nurjaya I.W. (2019). Kajian risiko penangulangan tumpahan minyak: studi kasus di Laut Jawa Bagian Barat. JPSL 9(3): 826-839, DOI: 10.29244/jpsl.9.3.826-839 [in Indonesian].

Shinn P., Austin C.P., Kavlock R.J. and Dix D.J. (2010). Analysis of eight oil spill dispersants using rapid, in vitro tests for endocrine and other biological activity. Environmental Science and Technology, 44, 5979-5985, DOI: 10.1021/es102150z.

Simanjorang J.E., Pranowo W.S., Sari L.P., Purba N.P. and Syamsuddin M.L. (2018). Building up the database of the Level-2 Java Sea Ecoregion based on physical oceanographic parameters. IOP Conf. Series: Earth and Environmental Science, 176, 012009.

Siregar S.N., Sari L.P., Purba N.P., Pranowo W.S. and Syamsuddin M.L. (2017). The water mass exchange in Java Sea due to periodicity of Monsoon and ITF in 2015. Depik Journal, 6(1), 44-55.

Siswanto and Suratno (2008). Seasonal pattern of wind-induced upwelling over Java - Bali Sea waters and surrounding area. International Journal of Remote Sensing Earth Science, 5, 46-56, DOI: 10.30536/j.ijreses.2008.v5.a1228. 
Solberg A.H.S., Brekke C. and Husøy P.O. (2007). Oil spill detection in Radarsat and Envisat SAR Images. IEEE Transactions on Geoscience and Remote Sensing, 45(3), 746-754, DOI: 10.1109/TGRS.2006.887019.

Sprintall J., Gordon A.L., Koch-Larrouy A., Lee T., Potemra J.T., Pujiana K. \& Wijffels S.E. (2014). The Indonesian seas and their role in the coupled ocean-climate system. Nature Geoscience, 7(7), 487-492, DOI: 10.1038/ngeo2188.

Sulistyono (2013). DampakTumpahan Minyak (Oil Spill) di Perairan Laut Pada Kegiatan Industri Migas and Metode Penanggulangannya. Forum Teknol. 3(1): 49-57 [in Indonesian].

Suneel V., Rao V.T., Suresh G., Chaudhary A., Vethamony P. and Ratheesh R. (2019). Oil pollution in the Eastern Arabian Sea from invisible sources: A multi-technique approach. Marine Pollution Bulletin, 146, 683-695, DOI: 10.1016/j.marpolbul.2019.07.015.

Topouzelis K. and Singha S. (2017). Oil spill detection using space-borne Sentinel-1 SAR Imagery. Oil Spill Science and Technology (Second Edition), Gulf Professional Publishing, Oxford, 387-402, DOl: 10.1016/B978-0-12-809413-6.00006-0. 